\title{
Intercultural Teaching Mode Construction of College English
}

\author{
He Feng \\ Feixian Campus, Linyi University Linyi, Shandong, China \\ wangyinuo_2007@163.com
}

Keywords: Intercultural Teaching Mode; Construction; College English.

\begin{abstract}
With the development of society and time, the teaching mode construction of new college English becomes inevitable. In order to meet the need of college English teaching and reform and improve the efficiency of English teaching, the author makes a detailed presentation to this teaching mode from teaching goal and content, teaching principles, teaching methods and teaching evaluation, discusses and puts forward the idea of the college English intercultural teaching mode which is also a reflection on the current foreign language teaching process with the hope of giving reference to other English teachers.
\end{abstract}

\section{Introduction}

With the development of society and time, the teaching mode construction of new college English becomes inevitable because of the plight of college English teaching and the need for talents with intercultural communication ability, which is also the responsibility of college English teaching of cultivating intercultural communication talents. In the process of thinking and exploration of this "inevitability", the paper is based on the combination of relevant theories and conception of intercultural transmission, college English teaching, analysis of the present situation and problems of the college English teaching, and attempts to construct the intercultural college English teaching mode which the main target is to cultivate students' intercultural communicative ability from the perspective of intercultural transmission. The author will have a detailed presentation to this teaching mode from teaching goal and content, teaching principles, teaching methods and teaching evaluation.

\section{Teaching Goal and Content}

Intercultural foreign language teaching developed quickly in the United States, Europe and other countries in recent 20 years. Byram (1994) and other scholars put forward a comprehensive teaching method combining language and culture, which is language-culture teaching method. After the investigation to the situation of culture teaching in European countries, Seele (1994) put forward a foreign language teaching mode of culture-based communicative competence and culture-based foreign language teaching. On the basis of these theories and the combination with the situation of college English teaching in China, the overall intercultural goal of foreign language teaching should be able to improve learners' language ability and communication skills and develop learners' intercultural communication competence. According to Hu Wenzhong (1999), language ability refers to the skills of language knowledge such as phonetics, vocabulary, grammar and the skills of listening, speaking, reading, writing and translating. Communication competence includes the ability to communicate appropriately, such as language competence and pragmatic competence. Intercultural communication competence is the ability to communicate using language knowledge and skills freely according to different context which surpasses specific language and cultural groups.

Intercultural goals of foreign language teaching include language skills, communication skills and the ability of intercultural communication, and its contents should include language teaching, cultural teaching and intercultural communication ability training. Specifically, language teaching contains the basic language knowledge and its use; cultural teaching includes cultural knowledge and communication; intercultural communication ability training includes intercultural awareness, intercultural communication competence and intercultural communication practice, etc. That is to say, 
in the process of intercultural foreign language teaching, through the learning of target language and culture, learners can master the target language knowledge, and communicate effectively with the target language group. At the same time, they can reflect on their own native language in learning, understand the general rules of language, the constitution, function and law of language development, the relationship between language, society and culture, experience, reflect culture in communication, compare target culture with native culture, and enhance their sensitivity to cultural differences and empathy. With the help and guidance of the teachers, learners can learn to adjust and solve intercultural communication problems such as cultural collision, misunderstanding and others difficulties. The three aspects of teaching contents are closely linked and mutually penetrated. Language knowledge and cultural knowledge act as the foundation, and language use and culture exchange provides practice and experience opportunities. Intercultural awareness can be trained in the process of knowledge learning and practice, which at the same time makes good preparations for learners to English learning and practice for the ultimate goal of cultivating intercultural communication competence in practice.

According to Gou Limei (2010), in productive foreign language teaching, native language and mother tongue culture play a positive role, and it has nothing to do with the substitution of cultural affiliation, emphasizes the interaction between the two languages and cultural value system. Thus, in foreign cultural teaching, the mother culture shouldn't be missed, and culture teaching shouldn't be imbalanced. Teachers should help student's form "productive foreign language learning", play the role of mutual promotion of these two kinds of language and culture to achieve the aim of intercultural communication. As Hall (1991) pointed out, "what hides behind culture is hardly known by its own participants. Years of research has made me believe that what we should do... is to understand one's own culture. I also believe that what people can get from the study of foreign culture is just on the surface of understanding. Such research is ultimately to have a better understanding of the activities of one's own language system." Hall also pointed out that interest and curiosity from the experience of the contrast and difference between the foreign culture and native culture are the best motivation for learning and understanding foreign culture.

\section{Teaching Principle}

The following two points are principles of intercultural foreign language teaching: the balance principle of culture teaching and the integrity principle of combining language teaching with culture teaching organically. In addition, intercultural foreign language teaching should also follow the following principles:

\subsection{Treat learners as the teaching focus and train their autonomous learning ability.}

Learners are the main body of teaching process, so the development of teaching should treat the learners as the focus and center on their needs. In intercultural foreign language teaching, the cultivation of learners' intercultural communication ability is also based on learners. As a result, when teachers design a lesson, the following aspects should be considered: the needs of the learners' language and culture learning, their experience, attitude, ability and so on. Learners as the teaching focus requires teaching them according to their aptitude. Different learners' have different learning style, learning methods and learning ability. English teaching should adopt different methods and appropriate guidance. Teaching students according to their aptitude and cultivating their autonomous learning ability is complementary to each other. Holec (1981) holds the view that autonomous learning means learners can be responsible for their own learning.

\subsection{Interactive Principle}

Interactive principle includes not only the interaction of language and culture but also the interactivity between Chinese and western culture, and also the interactive teaching and learning. Teaching should hold the developing view of language and culture, which is dynamic and interweaves each other. Intercultural foreign language teaching should also keep up with the pace of times and conduct in the interactive development. The relationship between Chinese and western culture should be equal and coexist. In the process of teaching and learning, the new teaching mode 
has changed traditional one-way transmission mode and emphasized the two-way transmission in the process of teaching communication and interaction. Teacher's teaching affects students' learning, and students' learning, in turn, affects teachers' teaching behavior. Intercultural communication itself requires two-way cultural communication and language itself is also produced and developed in communication. Therefore, intercultural foreign language teaching process should be interactive and give full play in students' learning participative enthusiasm to obtain better teaching effect.

\subsection{Teaching Methods}

Foreign language teaching has adopted the following several main teaching methods: grammar translation method, direct method, audio-lingual method, cognitive method, communicative method and others. Many scholars believe that, after nearly a century of "method age" with a variety of teaching styles, foreign language teaching entered into "post-method age". "Post-method age" teaching method attaches great importance to learning process, the construction of language knowledge, the cultivation of learning motivation and strategies, teacher's dominant and learners' autonomy to cultivate learners' ability of sustainable development ".

Either "method age" teaching method or "post-method age" teaching method, its formation has its era background and application environment. The growing teaching demand promotes the continuous updating development of the teaching method, so we can't be constrained and confined to a certain kind of teaching method, especially in intercultural foreign language teaching. Teachers should have the notion of "teaching with method but without a fixed method" and choose different teaching methods according to different teaching contents and teaching situation to achieve the best teaching effect. For example, teachers can use comprehensive teaching methods such as cognitive method with cognitive rules and grammar translation method to explain the basic grammar and language knowledge, combination of communicative approach and task-based teaching method as the main teaching process to achieve the goal of developing learners' comprehensive language ability and intercultural communication ability.

\section{Teaching Evaluation}

Culture is one of the main targets and contents of intercultural foreign language teaching, while the subjectivity and complexity of culture bring out the difficulties of culture test and evaluation. Qualitative assessment based on "authentic assessment" and "performance assessment" arose. Through the observation of the learners' learning process, it can make a comprehensive assessment according to learners' learning efforts, progress, learning attitude, and ultimate achievement, etc. Learners can also reflect on their own learning through the assessment process to promote and guide their autonomous learning. Therefore, intercultural foreign language teaching should take the assessment mechanism of combining formative assessment and summative assessment to give more objective and active feedback to the learners' learning and gain the positive learning effect.

Cultural knowledge is given priority to classroom teaching and "computer network" environment as teaching auxiliary. The five language skills of language adopt different teaching environment. The training of "listening" is mainly under the environment of "computer network", which facilitates the use of a variety of listening material, especially the rich original English listening material in internet, where can create the nearly real listening environment for students to go on appropriate interpretation supplemented by the classroom teaching of listening skills and methods. The training of "speaking" and "reading" can be conducted under the environment of "computer network", as well as in the classroom. Students can have the training of reading, speaking and pronunciation with the help of computer and network, at the same time have the interaction of analysis of the article content and genre and speaking. The training of "writing" and" translation" is given priority to classroom teaching and computer network environment being complementary, because teachers' face-to-face guidance is the most direct, targeted and effective for the two output skills training of writing and translation. Cultural communication is essential to English teaching, because all learning outcome is gained in the implementation of communication transmission, and the master of knowledge and skills should be used in it. There is no need to state the relationship between culture and communication 
transmission. More importantly, students can truly experience cultural differences, have an intuitive face-to-face to obstacles and problems of intercultural communication in the communication activities of practice, and under the guidance of teachers, their cultural sensitivity and intercultural communication consciousness can be cultivated, which could help them have a better understanding to culture shock to have flexible management and self-adaptation. The development of cultural communication can either use "computer network" environment, or in practice activities. In fact, from the view of students' intercultural communication needs and teaching training, the carry-out of the intercultural communication practice activities is an encouraging form, such as short-term foreign exchange visits, volunteer service activities of international conferences or establishment of the entity's intercultural communication practice experience exchange platform.

\section{Conclusion}

In today's global integration, international communication becomes increasingly frequent. The existence of cultural difference and possible communication barriers in intercultural communication are inevitable. So in the foreign exchange and dissemination, we must have a certain ability of intercultural communication to ensure smooth and effective communication.

Foreign language teaching has cleared the language barrier for the intercultural communication, and laid the intercultural dissemination foundation through language teaching. Intercultural communication should take advantage of foreign language teaching, combine the training of intercultural communication and foreign language teaching effectively to achieve win-win situation. In college English teaching reform, we should not only witness welcome progress in students' English learning, but also face the problems objectively existing in the current teaching mode. There are still many problems existing in college English teaching, such as emphasizing on language knowledge and skills but belittling cultural teaching, ignoring the input and output of mother tongue culture, culture teaching imbalance, lack of interaction and communication in teaching, neglecting the cultivation of intercultural awareness and the improvement of intercultural communication ability, and so on. We should work hard to explore and try out new English teaching mode. Based on the perspective of intercultural communication, the author tries to explore college English teaching and construct intercultural English teaching mode, which is a beneficial try to solve the dilemma.

\section{Acknowledgments}

The project is funded by the Center for Linguistics and Applied Linguistics, Guangdong University of Foreign Studies.

\section{Reference}

[1] Condon, J.C\& Yousef F.S. An Instruction to Communication (3 ${ }^{\text {rd }}$ ed.). Indianapolis: Bobbs-Merrill Company, 1975

[2] Halliday, M.A.K. Language as Social Semiotic: the Social Interpretation of Language and Meaning. London: Arnold, 1978

[3] Hall, E.T. Silent Language. New York: Doubleday, 1975

[4] Richards, J.C. and Rodgers, T.C. Approaches and Methods in Language Teaching. Cambridge: Cambridge University Press. 2000

[5] Seelye, H.N. Teaching Culture: Strategies for Intercultural Communication. Lincolnwood, Illinois: National Textbook Company, 1993 